\title{
Essais
}

ESSAIS

Revue interdisciplinaire d'Humanités

$4 \mid 2014$

Éducation et humanisme

\section{The Ground of the Imagination: An Interview with Jayne Anne Phillips}

Sarah Dufaure

\section{(2) OpenEdition \\ Journals}

Electronic version

URL: https://journals.openedition.org/essais/10059

DOI: 10.4000/essais.10059

ISSN: 2276-0970

Publisher

École doctorale Montaigne Humanités

Printed version

Date of publication: 15 April 2014

Number of pages: 149-155

ISBN: 978-2-9544269-2-1

ISSN: 2417-4211

Electronic reference

Sarah Dufaure, "The Ground of the Imagination: An Interview with Jayne Anne Phillips", Essais [Online], 4 | 2014, Online since 17 January 2022, connection on 20 January 2022. URL: http://

journals.openedition.org/essais/10059; DOI: https://doi.org/10.4000/essais. 10059 


\section{The Ground of the Imagination: An Interview with Jayne Anne Phillips}

\section{Sarah Dufaure}

Jayne Anne Phillips est une écrivaine américaine mondialement reconnue, née en 1952 à Buckhannon en Virginie Occidentale. Elle est l'auteur de recueils de poèmes (Sweethearts, 1976 ; Counting, 1978) et de nouvelles (Black Tickets, 1979 ; Fast Lanes, 1988) ainsi que de romans (Machine Dreams, 1984 ; Shelter, 1994 ; MotherKind, 2000). Son œuvre a été reproduite dans de nombreuses anthologies, traduite et publiée en douze langues et a fait l'objet d'importants travaux universitaires aux États-Unis et en Europe. Son dernier roman, Lark \& Termite (2009) a été nominé au National Book Award, l'une des distinctions littéraires les plus prestigieuses outre-Atlantique ayant déjà récompensé des écrivains comme Flannery O'Connor (1972, The Complete Stories), William Faulkner (1981, A Fable) ou Susan Sontag (2000, In America).

Jayne Anne Phillips a enseignéà Harvard, au Williams College et à l'Université de Boston. Elle est actuellement Professeure de Littérature à l'Université RutgersNewark dans le New Jersey où elle dirige des programmes de Master en arts visuels et performatifs, dont l'écriture d'invention. Elle travaille en ce moment sur un nouveau roman, Quiet Dell, qui sera publié par Scribners en octobre 2013.

Sarah Dufaure est doctorante monitrice à l'Université Bordeaux Montaigne. Après avoir rédigé un mémoire de Master sur l'imagination dialogique de Jayne Anne Phillips, elle se penche désormais sur la communauté d'écrivains du Sud des Appalaches et s'intéresse aux concepts de régionalisme et d'ancrage territorial en littérature. Son sujet de thèse, La Poétique de l'espace appalachien dans l'euvre de Jayne Anne Phillips et Meredith Sue Willis, se fonde sur les travaux phénoménologistes de Parks Lanier (The Poetics of Appalachian Space, 1991) et Gaston Bachelard (La Poétique de l'espace, 1961) et propose d'analyser leur application concrète dans les écrits de deux écrivaines contemporaines toutes deux nées en Virginie Occidentale.

Cet entretien a été réalisé en janvier 2013 dans le cadre de ses recherches doctorales. Il aborde les questions d'héritage culturel et d'identité géographique tout en explorant la dimension transfiguratrice et salvatrice de la littérature. 
Jayne Anne Phillips is an internationally acclaimed American writer who was born in Buckhannon, West Virginia, in 1952. She has written collections of poems (Sweethearts, 1976; Counting, 1978) and short stories (Black Tickets, 1979; Fast Lanes, 1988) as well as novels (Machine Dreams, 1984; Shelter, 1994; MotherKind, 2000). Her fiction has been widely anthologized, translated and published into twelve foreign languages, and has been the subject of academic discussion in the USA and in Europe. Her latest novel, Lark \& Termite, was a 2009 National Book Award Finalist.

Jayne Anne Phillips has taught at Harvard University, Williams College, and Boston University, and is currently Professor of English and Director of a MFA Program at Rutgers-Newark, the State University of New Jersey. She is now at work on a new novel, Quiet Dell, that will be coming out in October 2013 from Scribners.

Sarah Dufaure is a $\mathrm{PhD}$ candidate and teaching assistant at the University of Bordeaux Montaigne. After writing her Master's thesis on the dialogic imagination of Jayne Anne Phillips, her current research focuses on the community of writers in the Appalachian South, regional writing, and sense of place. Her dissertation topic-The Poetics of Appalachian Space in the Writings of Jayne Anne Phillips and Meredith Sue Willis-builds upon Parks Lanier's The Poetics of Appalachian Space (1991) and Gaston Bachelard's The Poetics of Space (1961) to explore the work of two West-Virginia born contemporary authors in the light of phenomenological philosophy.

This interview was carried out in January 2013 as part of her doctoral research and discusses the meaning of place and cultural heritage in fiction along with the transformative and safeguarding functions of literature itself.

\section{An important part of your fiction is set in West Virginia. How much has that place shaped you as a writer?}

My family, on both sides, had been in Western Virginia since the 1700s, pre-dating states and nations, when the land was territory. The sounds and smells and feel of that world, the mountains, the small towns, the fields around the house my father built, where I grew up with my brothers, are the ground of my imagination. It was where I became aware, became myself. West Virginia was an excellent beginning for a writer because there was such strong natural tension between the fact that it was a storyteller's world, a place of oral tradition, yet there were so many secrets, so much that you weren't supposed to talk about, so much knowledge of which no one spoke. Everyone just knew. That culture, its isolation and way of being, seemed a manifestation of the land itself, so green and mountainous, the only state enclosed completely in Appalachia, a world inside a world. 
Many people in Europe have been reading and responding to your work in very perceptive ways while having never heard of your West Virginian background and knowing almost nothing about Appalachia. I think Sarah Robertson is an exception, although her focus has probably been more Southern than Appalachian. What is your reaction to this? Is it gratifying in the sense that it proves how you have managed to transcend your regional heritage and become a universal writer, or do you rather think that it is a shame that the Appalachian dimension of your writing has gone almost unnoticed in Europe?

The Appalachian dimension is in my work no matter how one reads it; it's there factually, associatively, in events and character. Machine Dreams is clearly set in West Virginia, and both Shelter and Lark \& Termite have actual chapter or section headings titled "West Virginia." The fictional world of Bellington (the setting of Machine Dreams) is a mix of Belington, my mother's place of birth, and my hometown, Buckhannon; Winfield, the setting of Lark \& Termite, is the nearest town to Camp Shelter in Shelter; Winfield is a real town (my college roommate's hometown-I just loved the sound of the word); in my work, Winfield is located further north, near Bellington. Coalton, a rural hamlet in Randolph County, is mentioned in the books; my father's family was settled there in the late 1700s and gave the land for the town church and graveyard. Phillips Cemetery still exists; I remember going to funerals for my elderly aunts there when I was a child. If one has a conception of Appalachia, and of West Virginia as most central to Appalachia, it adds a dimension to reading the books, but they are certainly meant to be read as universal in meaning. West Virginia is very specific, but small town life happens all over the States, and all over the world. Family, histories of family strengths and dissolutions, war, time, sexuality, perception and dimensions of perception, are simply deepened by that sense of place and generational passage in literature.

It seems to me, but I may be projecting my own obsessions, that the "secret country" of your fiction is mostly a "divided country," torn apart between the desire to embrace universal concerns-drinking from the wellspring of Jung's collective unconscious-and the haunting presence of Appalachia to which you keep returning in your stories and novels. Could you comment on this pervasive sense of spiritual exile and your abiding kinship with West Virginia in your literary world?

The "secret country" is definitely a divided country, just as the conscious mind is "divided" from the unconscious: as above, so below. Male/female, age/ youth, gay/straight, passion/repression-each is "contained" in the "other," and the fear of a larger, inclusive awareness gives rise to tribal sensibility-whether the tribe is Methodists, NRA members, or Whatever. Jung's collective unconscious exists in the rural world, though it may be more frequently discussed in cities and university towns. For me, the "haunting presence" of Appalachia is unfailingly 
Jungian, and the tension of willed expatriotism-the need to leave a place to have the freedom to speak-is particularly rooted in my sense of place. I was fortunate to be drenched in a world, to grow up with an awareness of generations living and dying in one place for more than two hundred years. Tension and inner conflict are the energy of art. And there was not a "home place," the vast farm of my father's people, the thriving lumber mill and village of workers' houses by the river, of my mother's people-to keep me in that place. And I was female, very aware of the limited options and the struggle rural women face. As for spiritual exile, we are all spiritual exiles, in that we leave our families, our families of origin, or we pull away from them to create ourselves. The tension is in our attachments, because we are historical presences, and we continually work from a narrative that might be deep and inclusive, or narrow and blind. The writer is continually going deeper, braiding past and future.

In several essays and interviews, you have underlined your desire to "transform" your Appalachian hometown into mythic territory where the past can be redeemed. Could you tell me more about how these processes of "transformation" and "redemption" play out in your fiction and in your experience as a writer?

Writing has always seemed to me to be a redemptive act. Real life often seems random, a fluke of circumstance and timing, a political maelstrom layered in forgetfulness. Writers are the conscience of their culture and time; history gives us the facts, but literature tells us the story. Writing observes meaning, or creates meaning, within character. The world I knew, the world I absorbed by osmosis as a child, no longer exists in Appalachia, though worlds in such a certain place connect historically. Writing is not a career, but a calling, in the sense that passionate religious affiliation is a calling; writing is a practice, like a meditation practice in Buddhist belief, but the intent is not to empty the mind but to connect, to discern, to hear inside the actual sounds of language, elements that are genuine, specific, timeless. My particular experience, the ground of the yin/yang pull of opposites, began in place.

In his essay "Middle-Class Townie: Jayne Anne Phillips and the Appalachian Experience" published in a 1992 issue of Appalachian Journal, Avery Gaskins lamented over the lack of Appalachian "realism" in your work and stated that this lack was due, among other things, to your professors at West Virginia University who, at the time when you were attending that institution, were attempting to "lift students out of their 'narrowness' and to teach them to universalize, to get into the mainstream of American writing." What are your thoughts, a few decades later, now that you are an internationally acknowledged author, on this near vital necessity from local authors to break away from the restrictive and oppressive label of "regional writer"? 
Someone lamented over me? First I've heard. Well, I suppose plenty have, beginning with my own parents! See my comment on tribes, above. No professor in West Virginia ever spoke of "the mainstream" of American writing to me; they weren't that narrow-minded. "Regional writer" has always meant "locally interesting," that's why it's an insult. A dim-witted reviewer once compared me to "regional writer Eudora Welty." He managed to insult two writers at once and make his own misunderstandings public. To confuse regionalism with work set in the South, or in Appalachia, or in any specific place, is provincial. As for the 1992 essay above, I haven't read it, but I think it may have come out of a sense that "you can't belong to our club if you don't live here." Literature is not a club. There is good writing and bad writing. Eudora Welty remained geographically local most of her life, but she was a sophisticated artist, a great writer; she wasn't limited by local sensibilities; she subtly undercut them even as she celebrated the nuance and sound of place. The writer is deeply connected and yet set apart; he or she observes, looks, remembers, odd details perhaps, but associatively real moments. The artist is always the "other," inside a place, and the American tradition is to suspect the artist, the magician, the witch-especially the witch. Our Puritan forebears burned them. Powerful men are a dime a dozen; what is more threatening than a powerful woman? Perhaps part of what is acceptable in a very limited sense of what is "Appalachian" requires acceptance of a stereotype: poor, rural, male? Poverty is relative. My parents' old tax records reveal that a family of five lived on $\$ 10,000$ a year in the 60's; my father had only a year of college, in 1928, before he went to work, while my mother was only a thesis short of her doctorate. Her teacher's salary, when I was growing up, was the financial security of the family. I lived in the country, out a rural road, and was aware very young of the kids completely trapped in place, inside their families, inside grinding poverty from which there was almost no escape. Some writers need to leave in order to speak, to remember, to understand and move deeper. Others stay in place, threatened by other intimacies. The point is always the quality of the work.

In Joyce Dyer's Bloodroot: Reflections of Place by Appalachian Women Writers, many regional authors have emphasized the idea that they did not know there was such a thing as Appalachian literature until they grew up, moved out of the region, and got an education. You were an avid reader very early on. When did you start developing an interest in Appalachian fiction and are there any Appalachian writers who have influenced you or that you are currently reading?

This may have more to do with the fact that private schools are more rare in Appalachia than in other regions of the US, and public schools are at the mercy of state resources allowed them. Outsider cultures and groups tend to undervalue themselves; someone "legitimate" needs to assign value. That is changing. Projects like Kate Long's WV Public Radio "In Their Own 
Country" audio series interviews and presents readings by 14 West Virginia writers; the series was created as a resource for public schools. ${ }^{1}$ Kids are beginning to know, in West Virginia, that they have a literary heritage.

In "A View from Higher Ground: Meredith Sue Willis and the Appalachian Renaissance" Thomas E. Douglass directly links Meredith Sue Willis's writings to yours and other writers' through their common goal to think Appalachian literature anew, break out of stereotypes and imprisoning images, and reach out to embrace the world. How did you come to discover Meredith Sue Willis's work? What do you like about it? Do you acknowledge the idea that your work shares certain characteristics and goals with hers or do you think that it is totally different?

There is so much to admire about Meredith Sue and her work - she's an educator as well as a writer. And she works in various genres. My favorites are the Blair Ellen Morgan trilogy. The arc of those books seems autobiographical, though shot from within by so much Blair Ellen could never know. She's a memorable, place-centered character. And yes, we share in our work a deep rootedness in place, and a movement out into the world. Our methods of perception and obsessions are totally different, but we share an important bond.

There has been indeed an extraordinary Appalachian literary renaissance over the past 30 or 40 years in creative writing as well as academic study and criticism. Do you consider having personally taken part in this movement? Do you think it has contributed to improving the image of region and having Appalachian literature acknowledged on the national literary scene? How can writers born in Appalachia, having moved out or stayed in, write on the region in such a way that Appalachia become more than a splotch of assumptions and prejudices on the US map?

As they say, the best revenge is writing well. I'm not so concerned with "improving" the image of Appalachia. My sense memories are deep and abiding. I would never advise other writers on "how to write." Yes, one can talk about sentences, the arc and mechanics of story, but knowledge of place and depth of intent are not taught. Place can be a birthright central to all else.

Entretien mené par Sarah Dufaure,

Doctorante monitrice

Université Bordeaux Montaigne sarah.dufaure@u-bordeaux-montaigne.fr

1 See http://wvcenterforthebook.org/projects/In_Their_Own_Country.htm. 


\section{Mots-clés}

Jayne Anne Phillips, Littérature Américaine Contemporaine, Sentiment d'appartenance, Appalaches.

\section{Keywords}

Jayne Anne Phillips, Contemporary American Literature, Sense of Place, Appalachia.

\section{BIBLIOGRAPHIE}

Bachelard Gaston, La Poétique de l'espace (1957), Paris, Presses Universitaires de France, 2011.

Douglass Thomas E., "A View from Higher Ground: Meredith Sue Willis and the Appalachian Renaissance", The Iron Mountain Review: Meredith Sue Willis Issue, 12 (Spring, 1996), p. 13-18.

Dyer, Joyce (Ed.), Bloodroot: Reflections on Place by Appalachian Women Writers, Lexington, The University Press of Kentucky, 1998.

Gaskins Avery F., "Middle-Class Townie: Jayne Anne Phillips and the Appalachian Experience", Appalachian Journal, 19 (Spring, 1992), p. 308-316.

Lanier Parks (Ed.)., The Poetics of Appalachian Space, Knoxville, University of Tennessee Press, 1991.

Philipps Jayne Anne, Sweethearts, Durham, NC, Truck Press, 1976.

—-, Counting, New York, Vehicle Editions, 1978.

—, Black Tickets (1979), London and Boston, Faber, 1993.

—, Fast Lanes, London and Boston, Faber, 1988.

—-, Machine Dreams, London and Boston, Faber, 1984.

—-, Shelter, Boston and New York, Houghton Mifflin, 1994.

—, MotherKind, New York, Vintage, 2000.

—, Lark and Termite, New York, Alfred A. Knopf, 2009.

Willis Meredith Sue, "The Blair Ellen Morgan Trilogy": Higher Ground, Maplewood, NJ, Hamilton Stone Editions, 1981; Only Great Changes, Maplewood, NJ, Hamilton Stone Editions, 1985; Trespassers, Maplewood, NJ, Hamilton Stone Editions, 1997. 